\title{
Student Exchange Program Of Merdeka Belajar-Kampus Merdeka (MBKM) In Covid-19 Pandemic
}

\author{
Shelly Andari, Windasari, Aditya Chandra Setiawan, Ainur Rifqi \\ Universitas Negeri Surabaya \\ Email address: shellyandari@unesa.ac.id
}

\begin{abstract}
The MBKM student exchange program is conducted in the Department of Educational Management, FIP, State University of Surabaya. The program is implemented online considering the pandemic is still ongoing. This research has a high urgency because it is important to know how the management of MBKM student exchanges during the Covid19 pandemic, considering that so far student exchanges have been carried out directly or faceto-face before the Covid-19 pandemic. A qualitative approach with the case study method was used in this research. The results showed that student exchange management started from planning, organizing, implementing, to evaluating. The four steps are summarized in seven activities in the management of MBKM student exchange during the pandemic in the Department of Education Management, FIP Unesa, namely: (1) planning; (2) socialization; (3) recruitment; (4) student orientation; (5) student placement; (6) student development; and (7) recording and reporting. This study can be used as recommendations for the implementation of online student exchanges by other universities because it shows the process starting from program planning, organizing, implementing, to evaluation.
\end{abstract}

Keywords: student exchange program, MBKM, Covid-19 pandemic

The Policy on Independent LearningIndependent Campus or in Indonesia namely Merdeka Belajar-Kampus Merdeka (MBKM) is a policy of the Ministry of Education and Culture which will begin to be socialized in 2020. Through this MBKM policy students are given space to: (1) take 20 credits or the equivalent of 2 semesters outside of college; and (2) take 20 credits or 1 semester in different study programs within the same tertiary institution (Permendikbud No 3 2020 concerning Higher Education National Standards). This opportunity is given to students to be able to improve their competence, especially 6C (creativity, collaboration, communication, compassion, critical thinking, and computational logic). In addition, it is also necessary to develop student soft skills related to adaptation to new environments and the world of work later. MBKM seeks to answer major challenges related to the link and match between educational institutions and the Business and Industry World (DUDI).

The implementation of this policy almost coincided with the Covid-19 pandemic. As is well known, the Covid-19 pandemic has changed the way of life and habits of humans in almost all over the world, where people have to carry out social distancing (social distancing). This impact is also felt in the field of education where the implementation of education is carried out virtually by utilizing internet technology so that all activities can continue to run smoothly. On the other hand, online learning is an aspect that has made rapid progress in higher education (Xu and Morris, 2007). Songkram (2015) stated the same concept of learning method changes, where elearning makes students improve their cognitive aspect to achieve learning outcomes. With these changes, we must be adaptive in the midst of existing limitations, namely by developing internet-based student programs (Soudien, 2020). Activities that support the process of providing education are also carried out online, for example, student management, from recruitment, placement, development, evaluation, to student graduation, is carried out online. No exception, student exchanges that are usually carried out in person or face-to-face are now conducted online.

In general, student exchange activities are organized by two or more universities where one of the universities is "host" or as a destination university and the other is a university that sends students to study at that university. It is possible that the university which acts as a "host" also sends its students to study at partner universities. This depends on the agreement determined by the universities involved.

If examined more deeply, student exchange activities are included in the management of students in Education Management science. Student management starts 
from the student recruitment planning process. At this stage the planning is carried out by the leadership and a special committee formed for the recruitment of new students. Furthermore, the student recruitment plan that has been prepared is used as the basis for carrying out student recruitment activities. The recruitment of new students can be done with several models, for example the selection model using the test and the non-test selection model. After the recruitment, students are given provisions and knowledge about general school / university insights. This activity is referred to as student orientation. As stated in the Regulation of the Minister of Education and Culture No 552014 Article 2 states that the orientation period of students aims to introduce school programs and school culture so that the learning atmosphere can run conducive and educational goals can be achieved. Through this activity, the adaptation process of students is also expected to run optimally so that students feel comfortable in taking learning.

The next stage is the placement of students. This process is based on the criteria set by the special committee for recruiting students. Criteria can be reviewed in terms of the value or score obtained at the time of selection, specialization / major, or other criteria. Not only that, the placement of students also aims so that students are in the right environment to learn according to their characteristics (Saiffudin, 2014). After the placement process, students carry out a learning process which includes a competency development process based on their abilities and interests. The development activities implied in this learning process can emerge through the implementation of certain teaching methods, the learning resources used, study tours, internships, extracurricular activities, and others. Through the learning process and developing the good potential of students, the expected learning outcomes can be realized. The last stage is the evaluation and reporting stage. Students who have gone through the learning process follow the evaluation of learning outcomes which are then reported to students and parents. At this stage, if the student is at the final level of that level, then the student takes graduation. Conversely, if students are not at the final level of the level, then it is decided to continue to the next level or repeat.

The implementation of student management is closely related to student exchange management. Student exchange is a support program in the provision of education so that in the process it requires management starting from the recruitment of prospective exchange participants, orientation, placement, development, to evaluation of the learning outcomes of exchange participants. Student exchanges in the MBKM policy are expected to be able to realize the attitudes of students and graduates as contained in the Regulation of the Minister of Education and Culture (Permendikbud) No 2020, namely respecting cultural diversity, religious views and beliefs, as well as other people's original opinions or findings, as well as work. Equal and have social sensitivity and concern for society and the environment.

Student exchange activities for the MBKM program have been held by the Department of Education Management FIP Unesa since 2020. This activity is manifested in an effort to implement the MBKM, where student exchanges are carried out between departments / study programs of Management / Educational Administration throughout the LPTKs in Indonesia. In addition to hosting the student exchange program, the Department of Education Management, FIP Unesa, also sends its students to study in other LPTK departments / study programs for Education Management. In the process, this activity is of particular concern considering that all activities are carried out online due to the impact of the Covid-19 pandemic. As we know, so far student exchanges have only been carried out face-to-face because one of the objectives of student exchange is to exchange cultures from each region. However, during this pandemic it is impossible to do so. With social distancing to prevent the spread of the virus from spreading, the government decided to organize online student activities. Therefore, researchers seek to examine how the implementation of online student exchanges in order to know how is the implementation of online student exchanges by other universities.

It is still very difficult to find research or scientific articles that discuss about online student exchanges. This could be because the student exchange program has been temporarily suspended or is still in the planning stage by some universities that normally hold student exchange programs. Researchers did not find research related to online student exchanges, but researchers did find several studies that might support the importance of research related to online student exchanges during a pandemic.

The first research is from Ashiqin (2015) regarding the system that manages the implementation of student exchanges. In this study, it was explained that student exchange management, which was originally done manually, can now be replaced by an online integrated system. The system makes it easy for 
managers to manage the administrative files needed for the implementation of student exchange. Student exchange arrangements made by this application have high effectiveness compared to having to manually manage. This study does not discuss the management of online student exchanges but discusses the online system that regulates the implementation of student exchanges. The second study (Rajagopal, 2021) discusses virtual mobility which is designed to realize transformational learning. The concept of virtual mobility is that students from various countries can access learning from one of the universities or educational providers. Virtual mobility has been going on for several years in Europe and is carried out at the high school to tertiary levels. Some examples of virtual mobility programs are Professional and Cross-Cultural Skills in Engineering, Talk-Tech, Erasmus+ Virtual Exchange Online Facilitated Dialogue, EUMind Human Rights, EUMind GoGreen, and EUMind OnStage. This research shows that through virtual mobility encourage students to develop their intercultural skills, self-direct skills, and the ability in networking and collaborating. This study does not examine online student exchanges but at least discusses the implementation of virtual mobility which involves students in the online distance learning process. The third is research from McFarlane (2011) which discusses how to properly manage online learning or distance learning. The role of leaders in managing distance education is so important, for example by analyzing needs, meeting student needs, and evaluating whether these efforts can improve the quality of education. Leaders also have to understand how to coordinate with their staff even in remote and online conditions so that all learning needs are met.. This research shows that although learning is carried out online, its management requires full attendance from school leaders or managers.

Based on previous research, it is clear that there has been no research that focuses on online student exchange management so that this research has a high urgency to be carried out considering that there are no best practices that can be used as guidelines for implementing student exchanges during a pandemic. This research will reveal how online student exchange management is carried out, starting from planning, implementation, to evaluation. Through the data obtained, it will produce findings that are unique to the implementation of student activities during a pandemic, especially online student exchange programs.

\section{METHOD}

\section{Research Design}

Most of the data in this study can only be described through narrative, not numerical. So that a qualitative research approach is the right approach. This type of research used by researchers is a case study. The case study was chosen because the focus raised has its own uniqueness or uniqueness. Not many departments / study programs held student exchange programs at the time the MBKM socialization was held. The Department of Education Management with its initiative carried out student exchanges by inviting students from the Department / Study Program of Management / Administration of Education from university throughout Indonesia. In addition, this case is tied to the time and place where student exchanges are held for a certain period, especially during the Covid-19 pandemic so that implementation is required through virtual or online contact starting from planning meetings to evaluation and reporting.

\section{Data Collecting}

Data collection techniques used by researchers are interviews, observation, and documentation. Interviews were conducted with key informants in the implementation of the MBKM student exchange in the Department of Education Management, FIP Unesa, namely the Head of the Education Management Department, the Secretary of the Education Management Department, two lecturers who manage the courses taken by student exchange participants, and MBKM student exchange participants. The following are the criteria for selecting informants in this study.

\section{Table 1. Informants Criteria}

\begin{tabular}{|c|c|c|}
\hline No & Informant & Data \\
\hline 1. & $\begin{array}{l}\text { Head of the } \\
\text { Education } \\
\text { Management } \\
\text { Department }\end{array}$ & $\begin{array}{l}\text { Planning, organizing, } \\
\text { implementing, evaluating } \\
\text { MBKM student exchanges }\end{array}$ \\
\hline 2. & $\begin{array}{l}\text { the Secretary } \\
\text { of the } \\
\text { Education } \\
\text { Management } \\
\text { Department }\end{array}$ & $\begin{array}{l}\text { Planning, organizing, } \\
\text { implementing, evaluating } \\
\text { MBKM student exchanges }\end{array}$ \\
\hline 3. & $\begin{array}{l}\text { Two lecturers } \\
\text { who manage } \\
\text { the courses } \\
\text { taken by the } \\
\text { student } \\
\text { exchange } \\
\text { participants }\end{array}$ & $\begin{array}{l}\text { Implementation and } \\
\text { evaluation of MBKM } \\
\text { student exchanges }\end{array}$ \\
\hline 4. & $\begin{array}{l}\text { Two MBKM } \\
\text { student } \\
\text { exchange } \\
\text { participants }\end{array}$ & $\begin{array}{l}\text { Organizing, implementing, } \\
\text { and evaluating MBKM } \\
\text { student exchanges. }\end{array}$ \\
\hline
\end{tabular}


Initially the key informants were only the Chairman and Secretary of the Education Management Department, but researchers used snowball sampling technique where the researcher also obtained other informants based on the data obtained from the first informant. So that the informants in this study became six people with the details listed in Table 1.

Furthermore, the researcher selected the observation technique by making online observations on the Clinical Supervision Course (MK) and MK Educational Planning. Observations are made during lectures and researchers become passive observers because they only observe and do not participate in lecture activities. Meanwhile, the documentation technique is carried out by collecting documents related to the MBKM student exchange program. The documents compiled include the Implementation Agreement (IA), a list of student exchange participants, evaluation of the learning outcomes of student exchange participants, reports of student exchange activities, along with photos of activities carried out online. These documents can be used to justify the data obtained by researchers to corroborate findings in the field.

\section{Data Validity Checking}

Checking the validity of the data in qualitative research was carried out by testing the criteria, namely (1) credibility using triangulation, (2) transferability, (3) dependability, and (4) confirmability. The credibility test is carried out through method triangulation, namely by checking the data obtained from interviews, observations, and documents whether it is relevant or not and source triangulation, namely by checking the information obtained from one informant with another informant. Transferability is carried out by positioning the results of student exchange management research whether it can be arranged in different settings, for example different places and times. The dependability criterion refers to the benefits of research, namely that other researchers can develop similar research in different cases but still in the context of online MBKM student exchange. While the confirmability criteria are carried out by showing the results of the research to the informants so that there is a mutual agreement that the research results are truly objective and true..

\section{Data Analysis Technique}

The data analysis technique used by the researcher was the interactive model data analysis from Miles \& Huberman. The interactive model analysis consists of four major stages, namely: (1) data collection; (2) data reduction; (3) presentation of data; and (4) drawing conclusions / verification.
The researcher conducted an on-going data analysis during the research stage. After the researcher collected the data, the researcher performed data reduction by filtering the relevant data according to the research focus. At this stage the data becomes simpler and then grouped according to the focus of the study. The data group is coded so that it is easily recognized when presenting the data. Furthermore, the researchers made charts and matrices containing the research findings data. These charts and matrices make it easier for researchers and readers to understand the findings in the field. Charts and matrices are accompanied by descriptions that contain a more detailed explanation of the data displayed. In the last stage, the researcher checks the validity by triangulation and then a pattern will be formed regarding the research findings.

\section{RESULTS AND DISCUSSION}

\section{Planning for MBKM Program Student Exchange during the Covid-19 Pandemic}

The MBKM program student exchange activity was originally initiated by the head of the department (Kajur) and the head of the study program (Kaprodi) who are members of the APMAPI (Association of Indonesian Education Management and Administration Study Programs). The design was a response from the Kajur and the Head of Education Management / Administration study program to the MBKM policy issued by the Ministry of Education and Culture. On this stage, Educational Management Department realizes that as the part of Higher Education Institutions (HEIs), they must differentiate programs to attract public interest. It is often the number of applicants is based on the popularity of the education program they have (Frølich, 2009). It also proves that the universities as is an important factor in bringing novelty and innovation and it directly gives a positive impact to society (Mainardes, 2012). Furthermore, the design is realized by agreeing on the technical provisions for the implementation of student exchange. These provisions are compiled in the form of a Memorandum of Understanding (MoU) between Education Management / Administration study programs throughout Indonesia. The main program is student exchange with development activities that are free to be carried out by each study program according to their specifics. It shows that this collaborative process builds good and profitable relationship that may give positive impact in long term (Ryan, 2017). Head of the departments thought about how students of this generation in pandemic era expect to take 
advantage of the facilities and resources provided by their university so that they can develop their abilities, expand their networks, and take on new, more challenging opportunities (Khlaisang, 2019).

The planning technique in the Education Management Department involves the Head of the Education Management Department, the Secretary of the Education Management Department, and the MBKM team from the Education Management Department. In this activity, it is determined how the student recruitment process, courses programmed for student exchange activities, teaching lecturers, technical lectures, to evaluation or assessment of learning outcomes at the end of lectures. In addition, an exchange student orientation activity is also planned to be held before lecture activities in the Odd semester 2020/2021 begin. Planning meetings are held online using the Zoom Clouds Meeting application. Meetings were held three times involving the entire MBKM team. At this planning stage, stakeholders, namely graduate users and also policy makers, are involved. It proves that stakeholder influences the implementation of strategic planning in a university (Falqueto, 2020). This is in accordance with the results of Smith's research (2017) that educational institution partners need to be involved in the planning stages of student recruitment, regular programs or exchange programs. This makes the relationship between the university and stakeholders very important because it greatly affects the improvement of the quality of education (Cappiello and Padrini, 2017).

The socialization stage is carried out as the first step in the realization of the student exchange program plan. Socialization activities are carried out through social media, namely Instagram, Whatsapp, and the official website of the Department of Education Management. This socialization is carried out online and utilizes social media so that the information conveyed can be received effectively considering that currently students use almost all of their time to access smartphones. As stated by Zinn (2015) in his research, millennial generation (aged 17-34 years) use smartphones as part of their daily life and they are more able to adapt to existing technology to facilitate their work. The socialization process is carried out within a month to make the distribution of information more effective.
Furthermore, at the recruitment stage, prospective student exchange program participants are welcome to send a form containing personal data and their study interests at the destination university. At this recruitment stage, it tends to be simple because previously an MoU has been agreed between the Head of Study Program / Kajur at one university and another. So that recruitment is like the data collection stage for student exchange program participants. At this stage in-depth communication is important considering the recruitment process is in the $\mathrm{MoU}$ and it is important to pay attention to the existing provisions. In Gardner's (2019) study, the same thing was revealed that effective communication at the time of recruiting students is important to try to avoid technical problems that may arise.

\section{Implementation of the MBKM Program Student Exchange Program during the Covid-19 Pandemic}

The orientation of students participating in the exchange program is an environmental introduction activity held before lectures begin. Even though the lecture is held online, it is important that the introduction is made so that students get to know officials and lecturers of the Undergraduate Education Management Department, other student friends, lecture regulations, to technical lectures in the Education Management Department. As in previous research (Alperin, 2020), orientation activities aim to help students adapt to new environments, especially during the Covid-19 pandemic. This orientation activity was carried out on September 15, 2020, attended by Unesa FIP officials, the Head of the Education Management Department, the Secretary of the Education Management Department, and all lecturers and educational staff of the Education Management Department. In this orientation activity, it was conveyed that the MBKM student exchange program for the Department of Education Management was the first MBKM student exchange program in Unesa.

After the orientation activity, students are placed according to the class and lecture schedules are distributed. The distribution is based on the specializations submitted on the form at the time of program registration. The following are details of the placement of student exchange program students in the Department of Education Management. 
Table 2. Student Placement

\begin{tabular}{|c|c|c|c|}
\hline University & Department & Total & Course \\
\hline Universitas & Educational & 10 & Clinical \\
\hline $\begin{array}{l}\text { Negeri } \\
\text { Malang }\end{array}$ & Administration & & Supervision \\
\hline $\begin{array}{l}\text { Universitas } \\
\text { Negeri }\end{array}$ & $\begin{array}{l}\text { Educational } \\
\text { Management }\end{array}$ & 6 & $\begin{array}{l}\text { Strategic } \\
\text { Management }\end{array}$ \\
\hline Gorontalo & & & \\
\hline $\begin{array}{l}\text { Universitas } \\
\text { Negeri }\end{array}$ & $\begin{array}{l}\text { Educational } \\
\text { Management }\end{array}$ & 6 & $\begin{array}{l}\text { Project } \\
\text { Management }\end{array}$ \\
\hline $\begin{array}{l}\text { Universitas } \\
\text { Negeri } \\
\text { Padang }\end{array}$ & $\begin{array}{l}\text { Educational } \\
\text { Administration }\end{array}$ & 6 & $\begin{array}{l}\text { Educational } \\
\text { Organization } \\
\text { Developmen } \\
t\end{array}$ \\
\hline $\begin{array}{l}\text { Universitas } \\
\text { Negeri } \\
\text { Yogyakarta }\end{array}$ & $\begin{array}{l}\text { Educational } \\
\text { Sociology }\end{array}$ & 38 & $\begin{array}{l}\text { Educational } \\
\text { Organization } \\
\text { Developmen } \\
t\end{array}$ \\
\hline
\end{tabular}

Dhingra (2020) explains in his research that the placement of students based on specialization will have a positive impact on the achievement of learning outcomes, this is influenced by the motivation of students. Therefore, the placement based on specialization in the MBKM student exchange program is really taken into account so that student interest can be channeled.

The learning process takes place virtually by utilizing the Zoom, Google Classroom, and Google Meet applications. The learning method is not only lectures, but also group discussions oriented to project based learning. It emphasizes "not only the formal learning initiated in digital classrooms on campus but also the extended learning in which students continue peer discussions on the online platforms supported by mobile technology after class" (Kong, 2014).

\section{Evaluation of Student Exchange Learning for the MBKM Program during the Covid-19 Pandemic}

The lecture process is carried out online from the first meeting to the last (16th meeting). Exchange program students are required to take part in the lecture process, comply with all applicable regulations, and have the same rights and obligations as non-exchange students.

Students are required to fill in the online presence provided by the course lecturer. This presence is used as evidence that students are present in the lecture that is being carried out. Individual assignments and group assignments must also be done by students. The participation of exchange program students gives a different nuance in the middle of the learning climate of the Education Management Department. The challenges of learning in a new learning environment also train students' skills in adapting and solving problems. As stated by $\mathrm{Wu}$ (2015), new activities for student exchange program participants have a positive impact on student skills to have better resilience than before. Huang (2014) also mentioned that student-oriented activities help student to mastering their skills. Factors of successful virtual learning are preparing learning tools, learning resources, including the technology that is used will help improve the learning process (Asiri, 2012).

Middle Semester Examination and Semester Academic Examination are mandatory for students. As a result, reports on the results of student learning evaluations are sent to the Head of Study Program / Kajur at the original university so that they can be processed on their respective student accounts. The score awarded is the final score and there is no addition or subtraction. The results are the objective results of the student learning process. It shows that objective reflection of students and instructors is the importance of evaluation (Keller, 2020). As feedback provided by student exchange program participants, they are also required to prepare reports on student exchange activities in groups according to their respective university origins. As mentioned by Hwang (2015) that self-assessment, report, journaling, and peer sharing by student has a positive effect on learning achievement. The results of the learning evaluation are used to improve the quality of education in Education Management Department. Student evaluation is used to give an overview about the real condition in order to improve curriculum, learning processes, and strategic planning carried out by the institution (Liu, 2012).

\section{CONCLUSION}

The implementation of the MBKM program during the Covid-19 pandemic presented a special challenge for the tertiary institutions that were organizing the program. Activities that support the process of providing education are also carried out online, for example, student management, from recruitment, placement, development, evaluation, to student graduation, is carried out online. No exception, student exchanges that are usually carried out in person or face-to-face are now conducted online. The Education Management Department is the first department to organize a student exchange program. This program is held online starting from the planning, implementation, to evaluation stages. The entire process of activities involves policy makers or officials in Unesa and the Department of Education Management, the MBKM team, and stakeholders. This program was successfully implemented as part of the 
implementation of the MBKM in the Education Management Department.

The implication of this research is that it can be seen that the implementation of student exchange can be carried out online with the stages of planning, implementing, and evaluating. The implementation of student exchanges in the Department of Education Management, FIP Unesa, can be used as an example for the implementation of student exchange programs in the MBKM program by other universities. The results of this study can also be used as input by other researchers to examine the implementation of other MBKM programs both online and in the New Normal era. Suggestions for the institutions are they can formulate guidelines for the implementation of MBKM programs in order to increasing the quality of education.

\section{REFERENCES}

Ashiqin, N. (2015), Student Exchange Program Web Based Application System (Outbound), Universiti Teknologi Petronas, thesis unpublished.

Asiri, M. J. S., Mahmud, R., Bakar, K. A., \& Ayub, A. F. M. (2012). Factors influencing the use of learning management system in Saudi Arabian higher education: A theoretical framework. Higher Education Studies, 2(2), 125-137.

Cappiello, G., \& Pedrini, G. (2017). The performance evaluation of corporate universities. Tertiary Education and Management, 23(3), 304-317. DOI:https://doi.org/10.1080/13583883.2017. 1329452.

Dhingra, M. (2020). Factors affecting placement and hiring decisions: A study of students' perceptions. Journal of SAGE Publication: Industry and Higher Education, DOI:doi.org/10.1177/0950422220950191.

Falqueto, J.F.Z. (2020). Strategic planning in higher education institutions: what are the stakeholders' roles in the process?, Higher Education, 79, 1039-1056, DOI: https://link.springer.com/article/10.1007/s107 34-019-00455-8.

Frølich, N. (2009). Coping by Copying? Higher education institutions' student recruitment strategies, Tertiary Education and Management, 15 (3), 227-240, DOI: https://link.springer.com/article/10.1080/1358 3880903072992

Gardner, HR. (2019). Using evidence when planning for trial recruitment: An international perspective from time-poor trialists. PMC, Vol $14 \quad$ (12), $\quad$ DOI: 10.1371/journal.pone.0226081.

Huang, Y. M. (2014). Embedding diagnostic mechanisms in a digital game for learning mathematics. Educational Technology Research and Development, 62(2), 187-207.
Hwang, W.Y. (2015). Employing self-assessment, journaling, and peer sharing to enhance learning from an online course, Journal of Computing in Higher Education, 24, 114-133, DOI:

https://link.springer.com/article/10.1007/s125 28-015-9096-3.

Keller, J.M. (2020). A Combined Students' and Teachers' Online Education PerspectiveYou May Ask Yourself: Some Key Questions to Consider Before Beginning an Online Course or Program, Tertiary Online Teaching and Learning, 267-275, DOI: https://link.springer.com/chapter/10.1007/978 -981-15-8928-7 26.

Khlaisang, J. (2019). Designing a Virtual Learning Environment System for Teaching TwentyFirst Century Skills to Higher Education Students in ASEAN, Technology, Knowledge and Learning, 24, 41-63, DOI: https://link.springer.com/article/10.1007/s107 58-017-9310-7

Kong, S.C. (2014). A review of e-Learning policy in school education in Singapore, Hong Kong, Taiwan, and Beijing: implications to future policy planning, Journal of Computer in Education, $\quad 1, \quad 187-212, \quad$ DOI: https://link.springer.com/article/10.1007/s406 92-014-0011-0

Liu, O.L. (2012). Student Evaluation of Instruction: In the New Paradigm of Distance Education, Research in Higher Education, 53, 471-486, DOI:https://link.springer.com/article/10.1007 /s11162-011-9236-1

Mainardes, E.G. Universities Need a Market Orientation to Attract Non-Traditional Stakeholders as New Financing Sources, Public Organization Review, 14, 159-171, DOI:https://link.springer.com/article/10.1007 \%2Fs11115-012-0211-x.

Peraturan Menteri Pendidikan dan Kebudayaan (Permendikbud) Nomor 3 Tahun 2020.

Peraturan Menteri Pendidikan dan Kebudayaan Nomor 55 Tahun 2014 Pasal 2.

McFarlane, D.A. (2011). The Leadership Roles of Distance Learning Administrators (DLAs) in Increasing Educational Value and Quality Perceptions, Online Journal of Distance Learning Administration, Vol 4 (1), DOI: https://www.westga.edu/ distance/ojdla/sprin g141/McFarlane141.html

Rajagopal, K. (2021). Designing Virtual Mobility as a transformative learningexperience, EDUTEC, $75, \quad 9-30, \quad$ DOI: https://doi.org/10.21556/edutec.2020.74.1797

Ryan, C. (2017). Managing the Process of International Collaboration in Online Course Development: A Case-Example Involving Higher Education Institutions in Ireland, Switzerland, Austria, and the United Kingdom, Innovation Higher Education, 42, 451-462, DOI: 10.1007/s10755-017-9399-6 
Smith, LH. (2016). Effective Practices to Improve Recruitment, Retention, and Partnerships in School-based Studies. PMC, Vol 30 (5), 495498, DOI: 10.1016/j.pedhc.2016.05.004.

Songkram, N., Khlaisang, J., Puthaseranee, B., \& Likhitdamrongkiat, M. (2015). E-learning system to enhance cognitive skills for learners in higher education. Procedia Social and Behavioral Sciences, 174, 667-673.

Soudien, C. (2020). Complexities of difference and their significance for managing inequality in learning: Lessons from the COVID-19 crisis, PROSPECTS, 49, 59-67, DOI: https://link.springer.com/article/10.1007/s111 25-020-09486-x.

$\mathrm{Wu}, \mathrm{H}$. (2015). International Student's Challenge and Adjustment to College. Education Research International, DOI:https://doi.org/10.1155/2015/202753.

Xu, H., \&Morris, L. V. (2007). Collaborative course development for online courses. Innovative Higher Education, 32, 35-47.

Zinn, M. (2015). Student Recruitment for Mobile Generation. Master Thesis for Business Administration: Jonkoping International Business School. 